\title{
POPULATION MOBILITY CHARACTERISTIC: NOTES FROM THE URBAN-URBAN INTERACTION IN SEMARANG METROPOLITAN REGION
}

\author{
MARDHOTILLAH, Santi ${ }^{1} \&$ S. Sariffuddin ${ }^{2 *}$ \\ ${ }^{1,2}$ Department of Urban and Regional Planning, Faculty of Engineering, Diponegoro University \\ Jalan Prof. Sudarto, S.H., Tembalang, Semarang 50275 \\ *Corresponding author: sariffuddin@live.undip.ac.id
}

\begin{abstract}
The rapid growth of cities is characterized by the "pressure" in the form of increasingly dense urban areas, slums, traffic congestion, unemployment in the cities, and the number of illegal housing in the suburbs. This issue demonstrates the need for a balance between urban and rural areas. The balance is obtained through the interaction, and the interaction there is a process of "transfer" in the form of the human population, natural resources, and other supporting components. This view of the phenomenon makes many researchers conducting various studies in the context of the interaction between rural and urban. Furthermore, the study of the interaction of cities such as Salatiga and Semarang are in fact joined in the same region, KSN Kedungsepur. Semarang and surrounding developments as Semarang Metropolitan Region (SMR) are the main attraction for the people who are around Semarang that caused an increase in the spatial interactions between Semarang and surrounding areas. From some areas belonging to KSN Kedungsepur, there are only two areas with the status of the city of Semarang city as a centre of KSN and Salatiga. This becomes interesting, unique conditions for studying the phenomenon under study is the interaction of the cities. The method used in this research was a quantitative method with descriptive analysis. Data was collected through a questionnaire survey technique primary by taking a random sample of migrants from Salatiga City and studied at the city of Semarang. The results of the study there were four mobility characteristics formed between Salatiga and Semarang, namely, commuting-boarding, boarding-commuting, boarding and boarding-permanent.
\end{abstract}

Keywords: Mobility characteristic; mobility of society; urban-urban interaction.

\section{INTRODUCTION}

The attention of urban scholars in understanding the relationship of migration to urban development has entered the new phase. They are no longer just focus in debating the economic, social, and political aspects, but also they begin to link the issue with the urban space. Portes (2000) started this discussion through the research that resulted in 3 relationships between migration and cities, namely: first, the macrostructure and microstructure of the economy of the city are as determinant of migration/movement of labor; second, resistance to rules/policy towards international migration from developed countries and its impacts; and third, the role of urban area as a strategic center of global economy and the rising of transnational community as a family of the urban development. However, Portes was not alone in conducting this research. By using the concept of transnational mobility and urban spatiality, Collins (2011) concluded that the migrants in the cities of Asia Pacific form colonies that ultimately build a better settlement temporary or permanently. Although the supporting factors are different, a similar condition also occurs in Indonesia. Conversion of land in Java island reached 66.560 ha/year (Irawan, 2005), and it would negatively affect the sustainability of cities (Buchori \& Sugiri, 2016).

That concern is quite reasonable by seeing some similar phenomena in some countries in Asia and America. In India, the mobility of the population as one of the drivers of high urbanisation have degraded the quality of the environment (Datta, 2012; Hoelscher \& Aijaz, 2016) in the form of slum areas, pollution and congestion (Damayanti, 2011), which in turn interfere with the comfort of the city. The conditions are not much different from China (Dongfeng, Chengzhi, \& Ying, 2013) this condition also occurs in the United States (Winters \& Li, 2016). This issue led city planners to think from the perspective of internal urban planning using managing the environment. As did by the Government of Bandung (Duhita \& Virdianti, 2016; Satari, 2016) is not enough, the planners must also consider the external 'pressure'.

The rapid growth of cities, which is marked by the "pressure" of urbanisation, the increase of dense areas of slums, traffic congestion, urban unemployment, and the number of illegal houses in the suburbs. This issue demonstrates the need for a 
balance between urban and rural areas (Soegijoko \& Kusbiantoro, 1997; Pontoh \& Kustiwan, 2009; Putra $\&$ Pradoto, 2016). The balance is obtained through the interaction, further, in interaction contains a process of "transfer" in the form of the human population, natural resources, and other supporting components (Soegijoko \& Kusbiantoro, 1997). This view of the phenomenon makes many researchers conducting various studies in the context of the interaction between rural and urban. Furthermore, a question raises relate to the interaction of cities such as Salatiga and Semarang, these cities are in fact joined in the same region, namely KSN Kedungsepur. Some areas are incorporated in KSN Kedungsepur (Kendal, Demak, Ungaran, Salatiga, Semarang, and Purwodadi), the only two regions with the status of the city of Semarang city as a centre of KSN and Salatiga. It becomes interesting and unique conditions to study - the study of the urban-urban interaction.

Migration in the broader context of contemporary urban relates to contemporary urban where in this century are known to live in "urban age". It can be seen from by more than half the world's population currently lives in urban areas which cause uncontrolled population size as well as an unresolved problem (Brenner \& Schmid, 2014). On the other hand, the continued migration will have an impact on improving the welfare and affect the utilisation of urban space. This phenomenon usually occurs in developing countries, including Indonesia. It has been happening in Jakarta, which became a portrait of the formation of the "new city", it will appear an exclusive lifestyle. Then it began to create such kind of concentration of high-income group so that it automatically appears exclusively settlements centre (Firman, 2004). The gap phenomenon in the urban life, further, causes a subsequent impact on the provision of social needs and it also leads to high levels of violence in urban areas (Østby, 2015).

The impacts of migration have started to appear in the city of Semarang regarding both growth and population explosions. The growth of the city in the south brought the impact of gentrification on the side of social, economic, and physical; it can be seen in Tembalang as a result of the construction of Diponegoro University (Prayoga, Esariti, \& Dewi, 2013). Semarang is not only as the capital of Central Java, but it is also the centre of KSN Kedungsepur (Kendal, Demak, Ungaran, Salatiga, Semarang and Purwodadi), so, it led to almost a third of Kedungsepur's population live in city Semarang. KSN Kedungsepur population growth was recorded at $0.7 \%$ per year while the population growth of Semarang was $1.4 \%$ per year. KSN Kedungsepur population growth is high because it is influenced by a shift in the spatial distribution of the population. Therefore, by 2030, there will be about $36 \%$ of the population living in urban areas Kedungsepur Semarang (Mulyana, Dodman, Zhang, \& Schensul, 2013).

High population growth is due to the mobility characteristic, and mobility undertook by residents (Dwiyanto \& Sariffuddin, 2013). The mobility of the population is divided into two types, namely permanent and non-permanent mobility. Migration is the mobility of permanent residence (Boterman, 2012), it is included permanently transfer and change of residence status. The permanent migration of people to make the transition for six months or more and settled in the goal area. Mobility is the movement of non-permanent residents of an area to get to other areas with no intention of settling in the goal area. However, there has been no agreement among experts on the size of the area and the time limit in population mobility. Scale research used in research on population mobility also varies among researchers; this causes difficulties for researcher's mobility to use boundaries and standards/standard time. Non-permanent mobility present in two forms namely commuter/commuters and stay/boarding (Mantra, 2000).

Non-permanent mobility takes higher frequency than permanent mobility. It brings the impact of sustainable urban life, and it should get special attention to determine the direction of development of the city. In this research, we note a characteristic of population mobility between Salatiga and Semarang occurs as an impact of unbalance of needs supply and economic motives to improve well-being. Each of these mobility characteristics will bring a different effect because of the characteristics of perpetrators of mobility, and the causes of this characteristic formation of the mobility are also different. The different impacts of each of mobility characteristic give influence to the recommendations to the relevant stakeholders.

\section{RESEARCH METHODS}

The approach used in this study was the quantitative approach. This approach aims to test the theory, establish the fact, show the relationship between variables, provide a statistical description, assess and figure out the result (Sugiyono, 2010). The quantitative descriptive analysis technique used to determine the characteristic of population mobility caused by the interaction of Salatiga-Semarang. The population of this research are migrant from Salatiga 
that do the mobility to Semarang. Information on population mobility is very difficult to obtain from secondary data. This is due to the mobility of offenders not to register his departure to the office of the village chief or village where they came from. Thus, there are no exact figures on the number of population of this study. Therefore, the population is uncertain; the sampling is done using the formula from Wibisono (2013).

$$
\begin{aligned}
& \mathrm{n}=\left(\frac{Z_{\mathrm{x} / 2} \delta}{e}\right)^{2} \\
& \mathrm{n}=\left(\frac{(1.96) \cdot(0,25)}{0,05}\right)^{2} \\
& \mathrm{n}=96,04 \\
& \mathrm{n} \approx 97 \\
& \text { which: } \\
& \mathrm{n}=\text { number of sample } \\
& \mathrm{Z} \alpha=\mathrm{Z} \text { table } \\
& \sigma=\text { standard deviation of the population } \\
& \mathrm{e}=\text { error }
\end{aligned}
$$

The sampling technique in this research is accidental sampling which is done by taking a sample by chance met with investigators by the criteria of the sample. The criteria of the sample in this research are circular migrants from Salatiga that boarding in Semarang and have identity cards as proof of legal resident of Salatiga. Circular migrants from Salatiga in Semarang are students and workers (both formal and informal sectors). The population of circular migrants are uncertain, so as to measure samples taken $50 \%$ of students and $50 \%$ of workers both formal and informal sector workers. In the study obtained 112 questionnaires but there is some questionnaire with input data that is not feasible for the entry/ inconsistent and then do cropping. The survey had been doing for two months, from June to August 2016.

\section{RESULTS AND DISCUSSIONS}

Mobility characteristic formed by the mobility between Salatiga and Semarang was obtained from the questionnaire to the respondent to determine the mobility characteristic that respondents do before, during, and after Boarding. Based on research that has been done, their mobility characteristic can be divided into four kinds of characteristic, namely, commutingboarding, boarding-commuting, boarding and boarding-permanent. The four characteristics are caused by different conditions. This characteristic mobility influence on several matters related to the arrangement and urban management. Some things to note are that the traffic congestion, providing employment, integration locality in the area around the centre of growth, balancing the provision of infrastructure, and so on.

A Hundred respondents were divided into four mobility characteristics with the largest percentage (41\%) were boarding migrants (figure 1). This is consistent with the analysis that has been done, which consists of five factors (income, age, education level, the length of mobility, and marital status) that encourage migrants to undertake mobility from Salatiga City to Semarang. Furthermore, 20\% of migrants decided to become permanent migrants after the boarding. $23 \%$ of migrants decided to board after becoming commuters. This finding is in line with that expressed by Shuai (2012) which states that the act of commuting is capable of causing migration and mobility with higher mobility level. Some of the factors that influence the actions of commuting into the migration are the cost of commuting, migration costs, revenues, and facilities. On the other hand, the smallest percentage is Boarding-commuting by $16 \%$ migrant from Salatiga who became commuters after boarding.

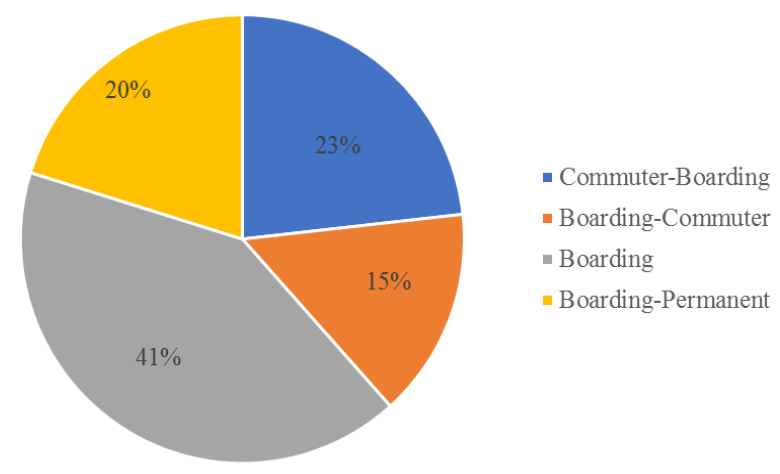

Fig. 1. Percentage Mobility Characteristic Formed in Salatiga Semarang

\section{Commuter-Boarding.}

The first mobility characteristic is commutersboarding. Before migrants decide to board, they initially become a commuter. There are $23 \%$ respondents were included in this mobility characteristic (figure 2). Some of the factors that affect this condition are the cost of commuting, migration costs, revenues, and facilities (Shuai, 2012). This is consistent with previous research that already exists in which these factors were able to prove that commuters can cause migration and mobility with a more permanent nature, in this case, is the Boarding. Below are the profiles of migrants belonging to the first characteristic; 


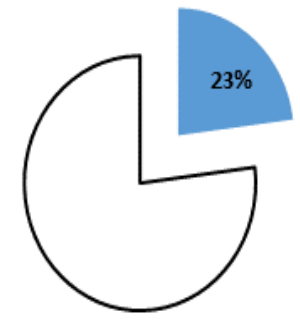

- $69 \%$ are $22-40$ years old (productive age)

- $56 \%$ male

- $52 \%$ Senior High Graduated

- $52 \%$ the third group income $(>1.900 .000)$

- $47 \%$ mariaged status

- $56 \%$ mobile for <4 years

Respondents profile of commuter-boarding

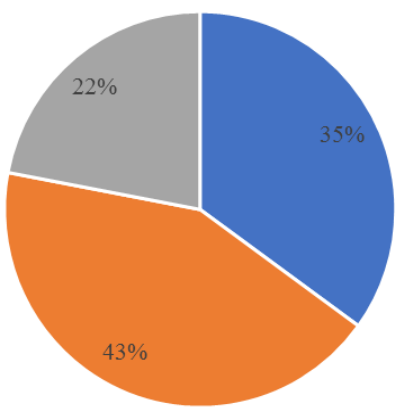

- Transportation Cost

- The demands of work

- Getting premium fasilities

The characteristic of commuter-boarding

Fig. 2. The Profile of Commuter-boarding

The majority of commuters decides to have a Boarding because of the demands of the job. The income they earn is already able to satisfy the need to hire a shelter or Boarding. Most respondents in this characteristic are the factory workers. Their employment depends on shift work and requires them to stay closer to the factory so that it is more profitable for them to settle temporarily in an area close to the factory. Some respondents in the mobility characteristic are a student, because the campus activities make them have Boarding house. These mobility characteristic led to the need for enhancing the provision of facilities, especially educational and transportation facilities to reduce the interest of people to migrate from Salatiga. Also, with the development of the facility also will add to the attractiveness of the city. Salatiga city is currently lacking attractive; even it is located between strategic areas and distinctively as Semarang and Solo. Development of public transport is also important to the city of Semarang because with the characteristic of population mobility initially turned into Boarding with the reason the cost of commuting. Meanwhile, the high mobility of the population living in Boarding House, in fact, have an impact on the need for the provision of housing for immigrants, especially the workers.

\section{Boarding-Commuting.}

Contrary to the previous characteristic, the second characteristic is Boarding-commuters. There are $16 \%$ of respondents who instead decided to become commuters after Boarding (figure 3). This characteristic will have a different impact on the previous characteristic for both Salatiga and Semarang City. The predicted impacts will arise with this characteristic in the form of traffic jams. Previously, these migrants profiles included the Boarding-commuting characteristic:

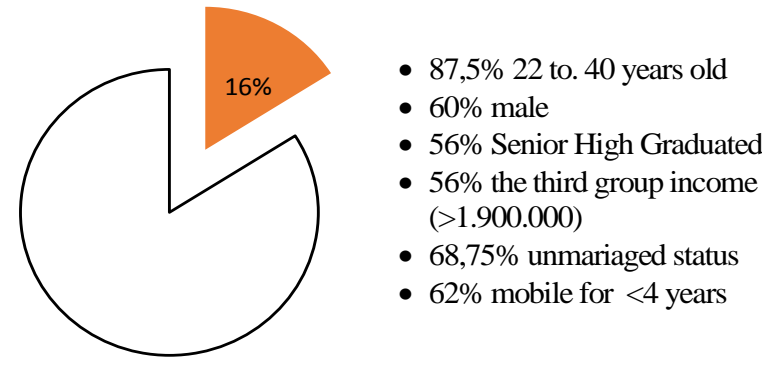

Respondents profile of boarding-commuting

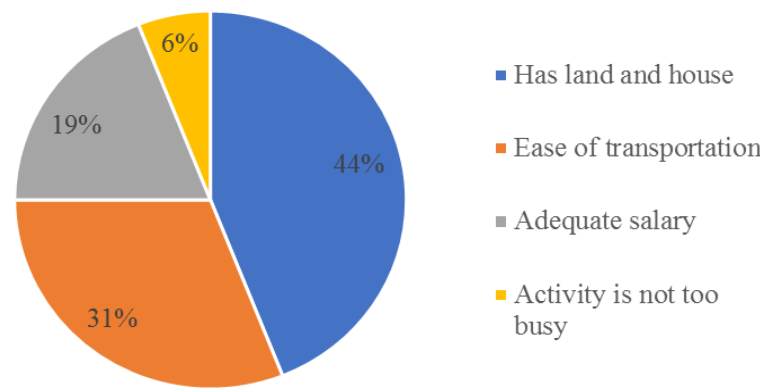

The characteristic of boarding-commuting

Fig. 3. Mobility Characteristic Profile of BoardingCommuting

The second characteristic is the Boardingcommuting, it became a minority mobility characteristic made by migrants from Salatiga in Semarang city. Recalling that commuting is a population movement to the destination and back in the same day to their home areas. Therefore, this mobility characteristic will have an impact in the form of traffic jams for Semarang due to population growth occurs when active working hours. The impact of traffic congestion makes Semarang must make transportation improvements with the hope of migrant easier mobility to public transport and reduce congestion by minimising the use of private vehicles. The decision to become a commuter migrant on the second characteristic is considered to have a minor impact in the city of Semarang because of population movements limited mobility, not until the migration has a dimension of permanent motion. Furthermore, the land owner or property in Salatiga and a relatively high income are predicted to have an impact on land tenure, especially in rural areas with land prices are still low. This is mostly done by migrants with fairly high income with investment reasons. 


\section{Boarding.}

The third mobility characteristic is boarding, in which migrants from early mobility in the form of Boarding - they are not commuters firstly - not interested to travel or settled permanently in the city of Semarang. By $73 \%$ of respondents claimed to have an interest in mobility to Semarang and 44 of them were included on this third characteristic of mobility actors (figure 4). The profiles are as follow:

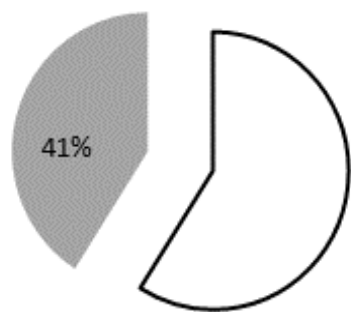

- $80 \%$ 22-40 years old

- $70,7 \%$ female

- $80 \%$ Senior High Graduated

- $51 \%$ the first group income $(<1.450 .000)$

- $78 \%$ unmariaged status

- $75 \%$ mobile for 4-8 years

Respondents profile of boarding

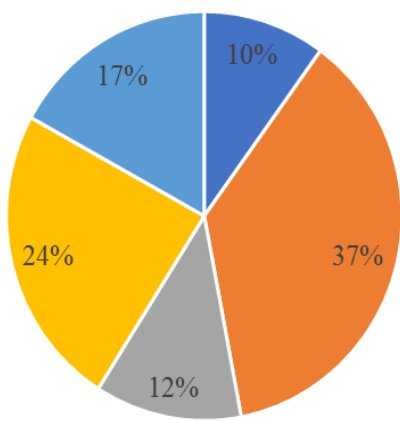

- To reduce transportation cost

- The demands of work

- Salary

- Property ownership

- Jobs

The characteristic of boarding

Fig. 4. Boarding Mobility Characteristic Profile

Semarang city as destination areas of migrants also gets impacted. Migrants, who are boarding to shift their residence on a temporary basis. Therefore, Semarang also needs to make the provision of shelter for migrants, especially workers. Provision of the residence will further affect the use of land in the city of Semarang. Provision of settlement as the residence of the migrants is needed to adapt to the characteristics of migrants to remain able to set the arrangement of the city regarding the settlement. The settings are also required to avoid the growth of slums because of the limited ability of immigrants to obtain a residence. It could occur because of migration cause dynamic effects in the form of income inequality between migrants and indigenous community. Inequality will be very high at the start of the migration, and will decrease after migrants became more established (Ha, Yi, Yuan \& Zhang, 2016). Provision of facilities for the residents by the Semarang Government will certainly be increased by the migrants.

\section{Boarding-Permanent.}

There are 20\% (figure 5) of respondents said that they were boarding at first, then they have a desire to settle in the city of Semarang. Many reasons influence the decision of a migrant to perform the migration. Here are profiles of migrants are included in the mobility characteristic Boarding-permanent:

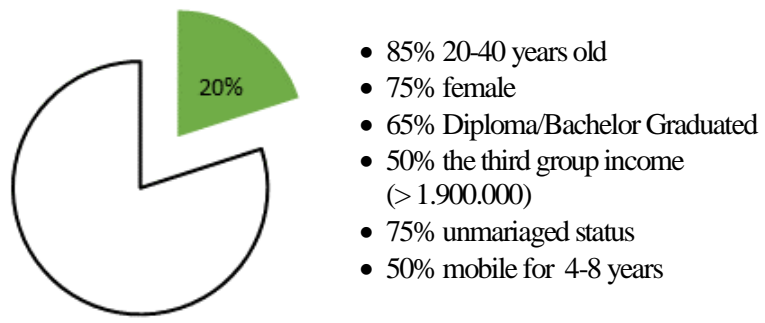

Respondents profile of boarding-permanent

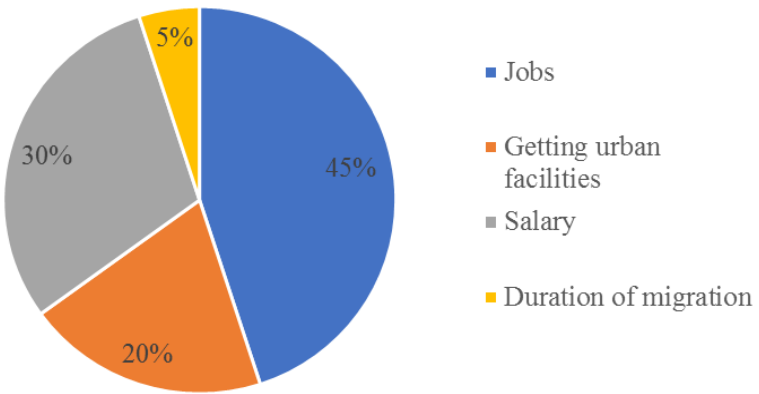

The characteristic of boarding-permanent

Fig. 5. Boarding-Permanent Mobility Characteristic Profile

Opportunities to obtain a job is the reason for migrants tending to be eager to settle in the area of the migration destination. It is in line with the acquisition of wages or income; income factor is also the reason for selecting migrants to settle in the city of Semarang. Income factors affect this mobility characteristic, especially for migrants with high incomes. On the other hand, for those who are still in school age, they tend to want to migrate and settle in the city of Semarang because they wish to acquire educational facilities with excellent service and better quality. A small part of migrants Salatiga who have a tendency to settle in the city of Semarang is driven by factors of length of mobility in the city of Semarang. Migrants who have long mobility are comfortable and are reluctant to return to their home areas. Semarang city is the centre of economic growth KSN Kedungsepur, which means it becomes the main attraction for the surrounding areas including Salatiga to be the purpose area of obtaining a better economic level. But it also will impact the city of Semarang including excessive population density. The majority of migrants decided to settle in Semarang. Population growth led to an increased need for housing and increased fulfilment city infrastructure to support the lives of its inhabi- 
tants. Finally, it will ultimately affect urban management in making the arrangement of urban space and facilities.

The area around the city of Semarang needs to pursue the relationship between localities with the production system and the global economy in the region for the welfare of the population and prevent the flow of migration (Wilonoyudho, 2014). Salatiga is included in this area, and it needs to make efforts to prevent migration flows. Salatiga migrants who decide to become permanent migrants are highly educated population and in productive age. Their migration motif is a combination of economic incentives and unbalances services in Salatiga. It can be proved from the reasons they chose to become permanent migrants are job creation and higher revenue they earn in Semarang. If labour in productive age and higher education (diploma/bachelor) leave Salatiga, it will result in losses for this city regarding ownership of qualified human resources. Also, the presence of such conditions is important for the city of Salatiga to perform a balancing infrastructure development, including education facilities, especially public universities and transportation facilities. In addition to adding to its attractiveness for Salatiga itself, it is also able to prevent the population of Salatiga.

From this research, the Benton-Short \& Price (2008) statement which says that the impact of globalisation has increased the movement of people between countries (transnational) and use the city as a container also occurs in a small scope. The city of Semarang as the city centre of the Semarang Metropolitan Region becomes the only container that should be able to accommodate people from around the city of Semarang. In fact, the city of Salatiga status is also not able to 'hold' its citizens to move to the city of Semarang with the aim of improving the quality of life. The imbalances occur so that this phenomenon exists in our society. These findings are in line with the Buchori \& Sugiri (2016, p. 1) statement, which states: "In Indonesia, the principles of equity have not been applied appropriately in regional and metropolitan development". Also, the attention to the development of the comfortable city can not only be seen from an internal perspective, that is through some concepts of development, such as revitalization, urban renewal and others, but also should pay attention to the external form of migration control perspective and equitable development.

\section{CONCLUSION}

Based on the results, this study concluded that there are four kinds of population mobility characteristic formed as a result of interaction between
Salatiga and Semarang. They are commuter-boarding, boarding-commuter, boarding and boarding-permanent. (1) Commuter-Boarding, the majority of migrants, are included in this characteristic because of the demands of the job depends on the work shift so that it is more profitable for them to settle temporarily in an area close to the factory. This characteristic will impact on the development of public transport (2) Boarding-Commuter, migrants chose to become a commuter, because they already have a land/house in Salatiga. This second characteristic brings an impact on traffic jams in the city of Semarang so that they need for transportation improvements to ease migrant mobility to public transport and reduce congestion by minimising the use of private vehicles. (3) Boarding, the majority of migrants in this characteristic are female and earn income in group $1(<1,450,000)$ that prefer to Board because of the demands of work and reduce the cost of transportation. This condition led Semarang to provide shelter for migrants, especially workers, by the characteristics of migrants to avoid the growth of slums because of the limited ability of immigrants to obtain a residence. (4) BoardingPermanent, this activity is done by migrants with high incomes. Opportunities to obtain employment is the reason migrants wishing to settle in the area of the migration destination. These conditions will have an impact in the city of Semarang including excessive population density. Population growth led to an increased need for housing and increased fulfilment city infrastructure to support the lives of its inhabitants.

Interests mobility of migrants from the city of Salatiga in Semarang is influenced by several factors such as age, education level of migrants, and the number of migrant mobility. The Economic motif is the major motif mobility of migrant Salatiga in Semarang City. Motif migrant to mobile is known from analyses of income and employment status of migrants. Migrant behaviour can be determined by analysing the sex of migrants and land tenure/property in origin area. There are several factors that affect migrants decide to migrate, both origin area factors and destination factors. Factors that come from Semarang is the age of migrants, migrant educational level, and marital status, while the income factor and the number of migrant mobility are a factor in purposed area. These five factors are directly proportional to the interests of migrant migration except the age factor. The younger migrant, the more they want to mobile. From these five factors, income factor is the most influential factor in the decision of migrant mobility. 


\section{REFERENCES}

Benton-Short, L. \& Price, M. (2008). Migrants to Metropolis: The Rise of Immigrant Gateway Cites, an Introduction. In M. Price \& L. BentonShort (Eds.), Migrants to the Metropolis: The Rise of Immigrant Gateway Cities. Syracuse, NY: Syracuse University Press.

Boterman, W. R. (2012). Residential Mobility of Urban Middle Classes in the Field of Parenthood. Environment and Planning A, 44(10), p.2397-2412. doi: http://dx.doi.org/10.1068/ a44558

Brenner, N. \& Schmid, C. (2014). The 'urban age'in question. International Journal of Urban and Regional Research, 38(3), p.731-755. doi: http://dx.doi.org/10.1111/1468-2427.12115

Buchori, I. \& Sugiri, A. (2016). An empirical examination of sustainable metropolitan development in Semarang City, Indonesia. Australian Planner, 53(3), p.163-177. doi: http://dx.doi.org/ 10.1080/07293682.2016.1151905

Collins, F. L. (2011). Transnational mobilities and urban spatialities. Progress in Human Geography, 36(3), p.316-335. doi: http://dx.doi.org/ $10.1177 / 0309132511423126$

Damayanti, R. (2011). Industrialization and Informal Sector in Shaping The City: Case Study Ahmedabad-India. DIMENSI (Journal of Architecture and Built Environment), 38(1), p.15-22. doi: http://dx.doi.org/10.9744/dimensi.38.1.15-22

Datta, A. (2012). India's Ecocity? Environment, Urbanisation, and Mobility in the Making of Lavasa. Environment and Planning C: Government and Policy, 30(6), p.982-996. doi: http://dx. doi.org/10.1068/c1205j

Dongfeng, Y., Chengzhi, Y. \& Ying, L. (2013). Urbanization and sustainability in China: An analysis based on the urbanization Kuznets-curve. Planning Theory, 12(4), p.391-405. doi: http://dx.doi. org/10.1177/1473095213485558

Duhita, D. \& Virdianti, E. (2016). Urban Community Responses to Visual Appropriate Thematic Design, Super Hero Park Bandung. Jurnal Pengembangan Kota, 4(2), p.169. doi: http://dx. doi.org/10.14710/jpk.4.2.169-176

Dwiyanto, T. A. \& Sariffuddin, S. (2013). Karakteristik Belanja Warga Pinggiran Kota (Studi Kasus: Kecamatan Banyumanik Kota Semarang). Jurnal Pengembangan Kota, 1(2), p.118127. doi: http://dx.doi.org/10.14710/jpk.1.2.118127

Firman, T. (2004). New town development in Jakarta Metropolitan Region: a perspective of spatial segregation. Habitat International, 28(3), p.349368. doi: http://dx.doi.org/10.1016/S0197-3975 (03)00037-7

Ha, W., Yi, J., Yuan, Y. \& Zhang, J. (2016). The dynamic effect of rural-to-urban migration on inequality in source villages: System GMM estimates from rural China. China Economic Review, 37, p.27-39. doi: http://dx.doi.org/ 10.1016/j.chieco.2015.09.002

Hoelscher, K. \& Aijaz, R. (2016). Challenges and opportunities in an urbanising India. International Area Studies Review, 19(1), p.3-11. doi: http://dx.doi.org/10.1177/2233865916637297

Irawan, B. (2005). Konversi lahan sawah: potensi dampak, pola pemanfaatannya, dan faktor determinan. Paper presented at the Forum Penelitian Agro Ekonomi.

Mantra, I. B. (2000). Demografi umum. Yogyakarta: Pustaka Pelajar.

Mulyana, W., Dodman, D., Zhang, S. \& Schensul, D. (2013). Urbanisation, Demographics and Adaptation to Climate Change in Semarang, Indonesia Technical Briefing (Vol. October 2013). Jakarta: UNFPA.

Østby, G. (2015). Rural-urban migration, inequality and urban social disorder: Evidence from African and Asian cities. Conflict Management and Peace Science, 33(5), p.491-515. doi: http://dx.doi.org/10.1177/0738894215581315

Pontoh, N. K. \& Kustiwan, I. (2009). Pengantar Perencanaan Perkotaan. Bandung: Penerbit ITB.

Portes, A. (2000). Immigration and the metropolis: Reflections on urban history. Journal of International Migration and Integration / Revue de l'integration et de la migration internationale, 1(2), p.153-175. doi: http://dx.doi.org/10.1007/ s12134-000-1000-x

Prayoga, I. N. T., Esariti, L. \& Dewi, D. I. K. (2013). The Identification of Early Gentrification in Tembalang Area, Semarang, Indonesia. Environment and Urbanization Asia, 4(1), p.57-71. doi: http://dx.doi.org/10.1177/110330881347 8606

Putra, D. R. \& Pradoto, W. (2016). Pola Dan Faktor Perkembangan Pemanfaatan Lahan di Kecamatan Mranggen, Kabupaten Demak. Jurnal Pengembangan Kota, 4(1), p.67. doi: http://dx. doi.org/10.14710/jpk.4.1.67-75

Satari, F. C. \& Larasati, D. (2016). What it takes for Bandung to Become a Creative City of Design. In D. L. W. Skoglund (Ed.), Valuing and Evaluating Creativity ofr Sustainable Regional Development. Ostersund, Sweden: UNESCO Creative Cities Network (UCCN). 
Shuai, X. (2012). Does Commuting Lead to Migration? Journal of regional analysis \& policy, 42(3), p.237-250.

Soegijoko, B. T. S., \& Kusbiantoro, B. (1997). Bunga Rampai Perencanaan Pembangunan di Indonesia. Jakarta: Grasindo.

Sugiyono. (2010). Metode Penelitian Kuantitatif Kualitatif dan R\&D Alfabeta. Bandung.
Wibisono, D. (2013). Panduan menyusun skripsi, tesis dan disertasi. Yogyakarta: $\mathrm{CV}$. Andi Offset.

Wilonoyudho, S. (2014). Migration and Involution in Semarang City. Jurnal Manusia dan LIngkungan, 21(1), p.114-120.

Winters, J. V. \& Li, Y. (2016). Urbanisation, Natural Amenities and Subjective Well-being: Evidence from US Counties. Urban Studies, p.1-18. doi: http://dx.doi.org/10.1177/0042098016631918 